\title{
MANAJEMEN KEUANGAN SEKOLAH DALAM RANGKA MENINGKATKAN MUTU PENDIDIKAN ISLAM DI SMAN1 PAPAR KEDIRI TAHUN PELAJARAN 2017/2018
}

\author{
Tri Erlinawati \\ Guru Sekolah Menengah Atas Negeri (SMAN 1) Papar Kediri \\ tr1erlinawatipapar@gamil.com \\ Badrus \\ Program Pendidikan Agama Islam Pascasarjana IAIT Kediri \\ badrus.kdr@gmail.com
}

\begin{abstract}
Abstrak.
Proses pendidikan dan pembelajaran merupakan kegiatan terencana yang dalam penyusunannya tidak dapat lepas dari faktor pembiayaan.Penelitian ini bertujuan untuk mengungkapkan strategi peningkatan mutu lembaga pendidikan Islam melalui manajemen keuangan di SMAN 1 Papar Kediri. Penelitihan ini difokuskan terkait perencanaan keuangan, Penggunaan dan pertanggungjawaban keuangan dalam meningkatkan mutu pendidikan Islam di SMAN 1 Papar dan implikasi manajemen keuangan dengan peningkatan mutu pendidikan Islam di SMAN 1 Papar pada tahun 2017/2018. Penelitian ini menggunakan pendekatan kualitatif dengan latar alamiah sebagai sumber datanya. Untuk mengumpulkan data disesuaikan dengan fokus dan pertanyaan serta tujuan penelitian, peneliti menggunakan teknik pengumpulan data meliputi observasi, wawancara mendalam dan kajian dokumen. Untuk mengungkapkan makna perilaku para informan penelitian telah mewawancarai kepala, wakil kepala, para guru, komite sekolah, dan siswa. Hasil penelitian setelah dilakukan analisis dan triangulasi data, adalah sebagai berikut: Pertama, Strategi manajemen pembiayaan pendidikan dalam peningkatan mutu guru, yaitu menekankan pada profesionalisme dan disiplin, serta komitmen tugas untuk meningkatkan mutu sekolah. Kedua, Strategi manajemen keuangan pendidikan dalam upaya pembinaan siswa dilakukan melalui pembinaan dibidang seni, olahraga, keagamaan, pramuka, bahasa Inggris, dan kepribadian. Keempat, Strategi manajemen keuangan pendidikan dalam bidang sarana dan prasarana dilakukan dengan memperbanyak sumber keuangan, menjalankan program peningkatan mutu untuk mendukung sarana dan prasarana serta kesejahteraan guru.
\end{abstract}

Kata kunci: Manajemen keuangan, mutu pendidikan Islam

\section{Pendahuluan}

Keuangan di sekolah pada garis besarnya berkisar pada uang sumbangan pembinaan pendidikan (SPP), uang kesejahteraan personel dan gaji, serta keuangan yang berhubungan langsung dengan penyelenggaraan sekolah seperti perbaikan sarana dan peningkatan mutu pendidikan. ${ }^{1}$
Pengelolaan keuangan secara umum sebenarnya telah dilakukan dengan baik oleh semua sekolah. Hanya kadar substansi pelaksanaannya yang beragam antara sekolah yang satu dengan yang lain. Adanya keberagaman ini sangat dipengaruhi oleh status sekolah bersangkutan, letak/lokasi sekolah serta jumlah siswa di sekolah itu sendiri. Pada

1 Sulistiorini, Manajemen Pendidikan Islam (Surabaya: Elkaf, 2006), h. 97. 
sekolah-sekolah biasa yang daya dukung masyarakatnya masih tergolong rendah, pengelolaan keuangannya masih sederhana. Sedangkan pada sekolahsekolah yang daya dukung masyarakatnya tinggi, tentu saja pengelolaan keuangannya cenderung menjadi lebih rumit. Kecenderungan ini dilakukan karena sekolah harus mampu menampung berbagai kegiatan yang semakin banyak dan beragam sesuai tuntutan masyarakat.

Pendidikan dianggap sebagai suatu investasi paling berharga dalam peningkatan kualitas sumber daya manusia untuk pembangunan suatu bangsa. Seringkali kebesaran suatu bangsa diukur dari sejauh mana masyarakatnya mengenyam pendidikan. Semakin tinggi pendidikan suatu bangsa maka semakin majulah bangsa tersebut. Kualitas pendidikan tidak hanya dilihat dari kemegahan fasilitas pendidikan yang dimiliki, tetapi sejauh mana output suatu lembaga pendidikan dapat membangun manusia yang paripurna sebagaimana tahapan pendidikan. ${ }^{2}$

Hasil penelitian yang dilakukan oleh lembaga survey pendidikan menunjukkan kemerosotan pendidikan di Indonesia. Pada tahun 2017 World Bank menyimpulkan kualitas pendidikan di Indonesia masih rendah. Survey yang melibatkan 50 negara di dunia menempatkan pendidikan Indonesia lebih rendah dibawah Brasil dan Meksiko. Survei dilakukan terhadap sistem pendidikan di 50 negara, dengan memadukan hasil tes internasional dan data-data, seperti tingkat kelulusan antara 2012 dan 2016 yang diambil berdasarkan tes setiap tiga atau empat tahun di berbagai bidang, termasuk matematika, sains, dan kesusastraan. ${ }^{3}$

Sementara berdasarkan data dalam Education for All (EFA) Global Monitroring Report 2011 yang dikeluarkan UNESCO dan diluncurkan di New York pada Senin, 1 Maret 2017, indeks pembangunan pendidikan Indonesia berada pada urutan 69 dari 127 negara yang disurvei. Lembaga

2 Deni Kuswara, Cepti Triatna, Manajemen Peningkatan Mutu Pendidikan (Bandung: Alfabeta, 2009), h. 287. yang selalu memonitor perkembangkan pendidikan di berbagai negara di dunia setiap tahun itu menempatkan kualitas pendidikan Indonesia masih lebih baik daripada Filipina, Kamboja, dan Laos. Tetapi apa artinya dengan membandingkannya dengan tiga negara yang memang selama ini peringkatnya tidak pernah berada di atas Indonesia. Survei ini menggunakan empat tolok ukur, yaitu angka partisipasi pendidikan menengah, angka melek huruf pada anak usia 15 tahun ke atas, angka partisipasi menurut kesetaraan jender, dan angka bertahan siswa hingga kelas XII di Jawa Timur saja beberapa waktu lalu pemerintah provinsi Jawa Timur mengumumkan dari 37 juta penduduk Jawa Timur masih terdapat kurang lebih 6 juta penduduk yang masih buta huruf. Begitu juga dengan tolok ukur mengenai kesetaraan gender dalam praktik pendidikan masih jauh dari angka ideal. Kendati isu kesetaraan jender terus dikumandangkan dan pemerintah secara khusus mengangkat menteri untuk menangani masalah perempuan, pembangunan kesetaraan gender masih menemui banyak kendala di Indonesia. Malah ada yang menganggap kesetaraan jender adalah agenda masyarakat Barat dan bertentangan dengan nilai budaya bangsa, lebih-lebih nilai agama (Islam).

Di Tingkat Asia saja saat ini Indonesia masih tertinggal dari Brunei Darussalam yang berada di peringkat ke-34. Brunai Darussalam masuk kelompok pencapaian tinggi bersama Jepang, yang mencapai posisi nomor satu Asia. Adapun Malaysia berada di peringkat ke-65 atau masih dalam kategori kelompok pencapaian medium seperti halnya Indonesia. Meskipun demikian posisi Indonesia saat ini masih jauh lebih baik dari Filipina (85), Kamboja (102), India (107), dan Laos (109).

Dari paparan di atas tampak jelas bahwa manajemen keuangan merupakan satu hal penting dalam upaya meningkatkan mutu pendidikan. Oleh karena itu peneliti

3 http://lpsa.or.id/lembaga-survey-pendidikanutama-pearson-mutu-pendidikan-indonesia-masihrendah/, diakses pada tanggal 26 Maret 2017. 
ingin menggali informasi dan temuan hasil penelitian yang berkenaan dengan manajemen keuangan atau pendanaan yang efektif dalam meningkatkan mutu pendidikan Islam di SMAN 1 Papar tahun pelajaran 2017/2018.

Pemilihan lokasi penelitian di SMAN 1 Papar sebagai tempat penelitian dengan pertimbangan sebagai berikut: SMAN 1 Papar merupakan sekolah umum negeri yang telah berusia 34 thn, letaknya strategis yang juga dekat dengan wilayah kota Nganjuk, jarak ke sekolah negeri lain cukup jauh, sarana dan prasarana yang dimiliki cukup lengkap dan memadai serta daya dukung masyarakat yang tergolong menengah kebawah.

Berawal dari fakta dan paparan latar belakang masalah di atas, peneliti tertarik untuk melakukan penelitian yang yang berfokus pada manajemen keuangan dengan judul "Manajemen keuangan di SMAN 1 Papar dalam rangka meningkatkan mutu pendidikan Islam tahun pelajaran 2017/2018".

Berdasarkan uraian di atas, maka penelitian ini difokuskan pada Manajemen Keuangan dengan rumusan masalah sebagai berikut : 1 . Perencanaan keuangan dalam meningkatkan mutu pendidikan di SMAN 1 Papar pada tahun 2017/2018. 2. Penggunaan dan pertanggungjawaban keuangan dalam meningkatkan mutu pendidikan di SMAN 1 Papar pada tahun 2017/2018. 3. Implementasi manajemen keuangan dengan peningkatan mutu pendidikan Islam di SMAN 1 Papar pada tahun $2017 / 2018$.

\section{Tinjaua Keuangan Sekolah Keuangan Sekolah}

Dalam

pendidikan, keuangan dan pembiayaan merupakan potensi yang sangat menentukan dan merupakan bagian yang tak terpisahkan dalam kajian manajemen pendidikan. Komponen keuangan dan pembiayaan pada suatu sekolah merupakan komponen produksi yang menentukan terlaksananya kegiatan belajar-mengajar di sekolah bersama dengan komponenkomponen yang lain. Dengan kata lain setiap kegiatan yang dilakukan sekolah memerlukan biaya, baik itu disadari maupun yang tidak disadari. Komponen keuangan dan pembiayaan ini perlu dikelola sebaik-baiknya, agar dana-dana yang ada dapat dimanfaatkan secara optimal untuk menunjang tercapainya tujuan pendidikan. Hal ini penting, terutama dalam rangka MBS, yang memberikan kewenangan kepada sekolah untuk mencari dan memanfaatkan berbagai sumber dana sesuai dengan kebutuhan masing-masing sekolah karena pada umumnya dunia pendidikan selalu dihadapkan pada masalah keterbatasan dana, apa lagi dalam kondisi krisis pada sekarang ini.

Berkaitan dengan peneriman keuangan dari orang tua dan masyarakat ditegaskan dalam Undang-Undang no. 20/2003 tentang Sistem Pendidikan Nasional bahwa karena keterbatasan kemampuan pemerintah dalam pemenuhan kebutuhan dana pendidikan, tanggung jawab atas pemenuhan dana pendidikan merupakan tanggung jawab bersama antara pemerintah,masyarakat dan orang tua. Adapun dimensi pengeluaran meliputin biaya rutin dan biaya pembangunan.

Biaya rutin adalah biaya yang harus dikeluarkan dari tahun ke tahun, seperti gaji pegawai (guru dan non guru), serta biaya operasional, biaya pemeliharaan gedung, fasilitas dan alat-alat pengajaran (barangbarang habis pakai). Sementara biaya pembangunan, misalnya, biaya pembelian atau pengembangan tanah, pembangunan gedung, perbaikan atau rehab gedung, penambahan furnitur, serta biaya atau pengeluaran lain unutk barang-barang yang tidak habis pakai. Dalam implementasi MBS, manajemen komponen keuangan harus dilaksanakan dengan baik dan teliti mulai dari tahap penyusunan anggaran, penggunaan, sampai pengawasan dan pertanggungjawaban sesuai dengan ketentuan yang berlaku agar semua dana sekolah benar-benar dimanfaatkan secara efektif, efisien, tidak ada kebocorankebocoran, serta bebas dari penyakit korupsi, kolusi dan nepotisme. 
Dalam pelaksanaannya manajemen keuangan ini menganut azas pemisahan tugas antara fungsi otorisator, ordonator dan bendaharawan. Otorisator adalah pejabat yang diberi wewenang untuk mengambil tindakan yang mengakibatkan penerimaan dan pengeluaran anggaran. Ordonator adalah pejabat yang berwenang melakukan pengujian dan memerintahkan pembayaran atas segala tindakan yang dilakukan berdasarkan otorisasi yang telah ditetapkan. Adapun bendaharawan adalah pejabat yang berwenang melakukan penerimaan, penyimpanan dan pengeluaran uang atau surat-surat berharga lainnya yang dapat dinilai dengan uang serta diwajibkan membuat perhitungan dan pertanggungjawaban.

Kepala sekolah dalam hal ini, sebagai manajer, berfungsi sebagai otorisator, dan dilimpahi fungsi ordonator untuk memerintahkan pembayaran. Namun, tidak dibenarkan melaksanakan fungsi bendaharawan karena berkewajiban melakukan pengawasan kedalam. Bendaharawan, disamping mempunyai fungsi-fungsi bendaharawan, juga dilimpahi fungsi ordonator untuk menguji hak atas pembayaran.

\section{Prinsip-prinsip Pengelolaan Keuangan Pendidikan}

Penggunaan anggaran dan keuangan, dari sumber manapun, apakah itu dari pemerintah ataupun dari masyarakat perlu didasarkan prinsipprinsip umum pengelolaan keuangan sebagai berikut, hemat, terarah dan terkendali sesuai dengan rencana, program/ kegiatan., terbuka dan transparan, dalam pengertian dari dan untuk apa keuangan lembaga tersebut perlu dicatat dan dipertanggung jawabkan serta disertai bukti penggunaannya, sedapat mungkin menggunakan kemampuan/ hasil produksi dalam negeri sejauh hal ini dimungkinkan

\section{Penyusunan Rencana Anggaran Keuangan Sekolah (RAKAS) \\ Suatu hal yang perlu diperhatikan dalam penyusunan RAKAS adalah harus}

menerapkan prinsip anggaran berimbang, artinya rencana pendapatan dan pengeluaran harus berimbang diupayakan tidak terjadi anggaran pendapatan minus. Dengan anggaran berimbang tersebut maka kehidupan sekolah akan menjadi solid dan benar-benar kokoh dalam hal keuangan, maka sentralisasi pengelolaan keuangan perlu difokuskan pada bendaharawan sekolah, dalam rangka untuk mempermudah pertanggung jawaban keuangan.

Rencana tersebut setelah dibahas dengan pengurus dan komite sekolah, maka selanjutnya ditetapkan sebagai anggaran pendapatan dan belanja sekolah (APBS). Pada setiap anggaran yang disusun perlu dijelaskan apakah rencana anggaran yang akan dilaksanakan merupakan hal baru atau kelanjutan atas kegiatan yang telah dilaksanakan dalam periode sebelumnya dengan menyebut sumber dana sebelumnya.

\section{Realisasi RAKAS}

Dalam pelaksanaan kegiatan, jumlah yang realisasikan bisa terjadi tidak sama dengan rencana anggarannya, bisa kurang atau lebih dari jumlah yang telah dianggarkan.

\section{Pertanggung jawaban Keuangan Sekolah}

Semua pengeluaran keuangan sekolah dari sumber manapun harus dipertanggung jawabkan, hal tersebut merupakan bentuk transparansi dalam pengelolaan keuangan. Namun demikian prinsip transparansi dan kejujuran dalam pertanggung jawaban tersebut harus tetap dijunjung tinggi. Dalam kaitan dengan pengelolaan keuangan tersebut, yang perlu diperhatikan oleh bendaharawan adalah:

\section{Mutu Pendidikan}

Strategi berarti rencana yang cermat mengenai kegiatan untuk mencapai 
sasaran yang khusus. ${ }^{4}$ Dulu strategi digunakan dalam kegiatan berperang, tetapi istilah ini kemudian dapat diterapkan dalam berbagai lingkup kehidupan diartikan sebagai rencana yang cermat mengenai kegiatan untuk mencapai sasaran khusus. Peningkatan memiliki kata dasar tingkat ditambahi imbuhan pesan sehingga menjadi peningkatan yang berupa kata benda dengan arti proses, cara, perbuatan meningkatkan sesuatu. ${ }^{5}$ Selanjutnya mutu adalah baik buruk suatu keadaan. Mutu mengandung makna derajat (tingkat) keunggulan suatu produk (hasil kerja) baik berupa barang maupun jasa, baik yang tangible maupun yang intangible. Beberapa konsep mutu yang diutarakan oleh Abdul Hadis, dan Nurhayati, dalam Manajemen Mutu Pendidikan menurut para ahli yaitu:

Menurut Juran , mutu produk ialah kecocokan penggunaan produk (fitness for use) untuk memenuhi kebutuhan dan kepuasan pelanggan. Kecocokan pengguna produk tersebut didasarkan atas lima ciri utama yaitu (1) teknologi; yaitu kekuatan; (2) psikologis, yaitu rasa atau status; (3) waktu, yaitu kehandalan; (4) kontraktual, yaitu ada jaminan; (5) etika, yaitu sopan santun.

Menurut Crosby mutu ialah conformance to requirement, yaitu sesuai dengan yang disyaratkan atau distandarkan. Suatu produk memiliki mutu apabila sesuai dengan standar atau kriteria mutu yang telah ditentukan, standar mutu meliputi bahan baku, proses produksi, dan produk jadi .

Menurut Deming mutu ialah kesesuaian kebutuhan pasar atau konsumen. Perusahaan yang bermutu ialah perusahaan yang menguasai pangsa pasar karena hasil produksinya sesuai dengan kebutuhan konsumen, sehingga menimbulkan kepuasan bagi konsumen. Jika konsumen merasa puas, maka mereka akan setia dalam membeli produk

\footnotetext{
4 Kamus besar bahasa Indonesia, Pusat Bahasa Departemen Pendidikan Nasional, Jakarta: Balai Pustaka, 2001. 708

${ }^{5}$ Kamus besar bahasa Indonesia, Hal.677

${ }^{6}$ Hadis, Abdul \& Nurhayati, Manajemen Mutu Pendidikan. Bandung: Penerbit AlfaBeta, 2010,84-85
}

perusahaan baik berupa barang maupun jasa.

Menurut Feigenbaum mutu adalah kepuasan pelanggan sepenuhnya (full customer satisfication). Suatu produk dianggap bermutu apabila memberikan kepuasan kepada konsumen, yaitu sesuai dengan harapan konsumen atas produk yang dihasilkan.

Garvi dan Davis menyatakan mutu ialah suatu kondisi yang berhubungan dengan produk, tenaga kerja, proses dan tugas serta lingkungan yang memenuhi atau melebihi harapan pelanggan. ${ }^{6}$

Dari beberapa konsep mutu yang diutarakan oleh para ahli, maka penulis mengambil kesimpulan bahwa mutu merupakan suatu ukuran yang berhubungan dengan kepuasan pelanggan terhadap sebuah produk. Menurut Sallis dalam Thomas mengatakan bahwa mutu dapat diartikan sebagai derajat kepuasan luar biasa yang di terima oleh pelanggan sesuai dengan kebutuhan dan keinginannya. ${ }^{7}$ Menurut Marus Suti, mutu dapat dilihat dari dua sisi yaitu segi normatif dan segi diskriptif. Dalam arti normatif mutu berdasarkan pertimbangan instrinsik, mutu pendidikan merupakan produk pendidikan yakni manusia yang terdidik sesuai standar ideal. Sedangkan secara ekstrinsik, pendidikan merupakan instrument untuk mendidik tenaga kerja yang terlatih. Dalam arti deskriptif, mutu ditentukan berdasarkan keadaan senyatanya misalnya hasil tes. ${ }^{8}$

Dengan demikian, penulis simpulkan bahwa mutu pendidikan adalah derajat keunggulan dalam pengelolaan pendidikan secara efektif dan efisien untuk melahirkan keunggulan akademis dan ekstra kulikuler pada peserta didik yang dinyatakan lulus untuk satu jenjang pendidikan atau menyelesaikan pembelajaran tertentu. Mutu dalam konteks "hasil pendidikan" mengacu pada prestasi

7 Thomas, Partono. " Faktor Determinan Produktivitas Sekolah", Jurnal Penelitian dan Evaluasi Pendidikan Tahun 17, Nomor 1, 2013, 3

8 Marus Suti, Strategi Peningkatan Mutu di Era Otonomi Daerah, Jurnal MEDTEK, Volume 3, Nomor 2, Oktober 2011,5 
yang dicapai sekolah pada kurun waktu tertentu. Prestasi yang dicapai dapat berupa hasil tes kemampuan akademis (misalnya ulangan umum, UN atau UAMBN). Dapat pula prestasi di bidang lain seperti prestasi di suatu cabang olah raga,seni atau keterampilan. Bahkan prestasi sekolah dapat berupa kondisi yang tidak dapat dipegang (intangible) seperti suasana disiplin, keakraban,saling menghormati, kebersihan, dsb.

Achmad mengemukakan bahwa, mutu pendidikan di sekolah dapat diartikan sebagai kemampuan sekolah dalam pengelolaan secara operasional dan efesien terhadap komponen yang berkaitan dengan sekolah, sehingga menghasilkan nilai tambah terhadap norma atau standar yang berlaku. ${ }^{9}$ Apapun yang dilakukan harus berpatokan pada aturan dan standar. Ada banyak pendapat mengenai kriteria mutu pendidikan. Mutu pendidikan menurut standar nasional pendidikan adalah pendidikan yangmenghasilkan lulusan sesuai dengan harapan masyarakat, baik dalam kualitas pribadi, moral pengetahuan maupun kompetensi kerja.

Mutu merupakan sebuah konsep yang kontradiktif sebab di satu sisi mutu dapat diartikan sebagai konsep yang absolut dan di sisi lain bisa diartikan konsep yang relatif. Sebagai konsep yang absolut, mutu dipahami sebagai dasar penilaian untuk kebaikan dan kebenaran yang memungkinkan standar tinggi dan tidak dapat diungguli. Sedangkan mutu yang bersifat relatif ialah mutu dapat dinilai terus kelanjutannya, mutu merupakan produk konseptual yaitu apa yang dianggap sekarang bermutu belum tentu besok bisa dianggap bermutu sehingga perlu adanya perbaikan terus menerus. Secara terminologi mutu telah didefinisikan secara beragam, Edward Dening mendefinisikan mutu sebagai " kesesuaian dengan kebutuhan pasar", dari definisi ini, Armand V. Feigenbaun mengatakan ukuran relatif dari suatu produk atas jasa sesuai dengan standar mutu desain. Mutu desain meliputi

9 Dedy,Achmad, Pengelolaan Pembiayaan Sekolah Dasar di Bandung, Jurnal Penelitian Pendidikan Vol.12. No I, April 2011, 5. spesifikasi produk dan mutu kesesuaian, yaitu seberapa jauh suatu produk telah memenuhi persyaratan yang telah ditetapkan. Dengan berbagai pengertian mutu tersebut maka manajemen mutu berarti sebagai keseluruhan metode untuk mengatur mutu dalam suatu organisasi yang meliputi produk, jasa, kinerja, proses dan sumber daya manusia. Manajemen mutu menggabungkan trilogi mutu, yaitu perencanaan mutu, pengendalian mutu, dan perbaikan mutu. ${ }^{10}$

Dengan demikian dapat simpulkan bahwa mutu pendidikan bukan ditentukan dari lembaga penyelenggara pendidikan tetapi mutu pendidikan adalah spesifikasi yang dikehendaki dan kesesuaian dengan apa yang menjadi pandangan serta harapan masyarakat, dengan mengoptimalkan keseluruhan penunjang mutu pendidikan, yaitu input, proses, sehingga akan menghasilkan kualitas output mutu pendidikan yang tinggi.

\section{Metode Penelitian}

Penelitian ini menggunakan pendekatan kualitatif. Diharapkan dengan metode ini mampu menghasilkan uraian yang mendalam tentang ucapan, tulisan, dan perilaku yang diamati dari suatu individu, kelompok, masyarakat, organisasi dalam suatu setting konteks tertentu yang dikaji dari sudut pandang yang utuh, komprehensif dan holistik. Penelitian deskriptif menggambarkan kegiatan penelitian yang dilakukan pada objek tertentu.

Dalam penelitian kualitatif, narasumber adalah orang yang menjadi sumber informasi. Narasumber melibatkan orang yang berperan sebagai orang kunci (key person) atau orang yang berkompeten yaitu kepala sekolah sebagai pemimpin di sekolah yang bertanggungjawab terhadap semua kegiatan yang ada di sekolah, bendahara, komite sekolah, guru, karyawan, siswa dan wali murid. Dasar pemilihan nara sumber adalah adanya pertimbangan untuk memberikan

10 Ara Hidayat dan Imam Machali, Pengelolaan Pendidikan (konsep, prinsip dan aplikasi dalam mengelola sekolah dan madrasah ), 320-321. 
informasi guna menjawab permasalahanpermasalahan penelitian. Pemilihan informan atau key person ini dilakukan secara purposif atau sesuai dengan tujuan fokus permasalahan.

Adapun analisis data yang digunakan dengan model analisis interkatif yaitu: (1) reduksi data; (2) penyajian data; dan (3) penarikan kesimpulan atau verifikasi (Miles dan Huberman dalam Sugiyono. ${ }^{11}$

\section{Hasil Penelitian \\ Perencanaan Pembiayaan di SMAN 1 Papar Kediri}

Biaya pendidikan yang ada di SMAN

1 Papar Kediri adalah berupa biaya operasional yaitu biaya yang dikeluarkan oleh sekolah yang secara langsung menunjang penyelenggaraan pendidikan. Biaya operasional di sekolah digunakan untuk memenuhi pengeluaran rutin sekolah dan pengeluaran non rutin sekolah meliputi pemeliharaan sarana dan prasarana, pengadaan inventarisasi sekolah, rekening listrik dan telepon, pajak serta kegiatankegiatan ekstrakulikuler.

Sumber keuangan dan pembiayaan pada sekolah secara garis besar dapat dikelompokkan atas beberapa sumber yaitu (1) pemerintah baik pemerintah pusat melalui APBN melalui Dana BOS, (2) orang tua, (3) dana masyarakat, (4) usaha ekonomi sekolah, dan (4) sumber lain yang tidak mengikat.

Anggaran di SMAN 1 Papar Kediri merupakan rencana pemasukan dan pengeluaran yang digunakan sebagai pedoman melaksanakan kegiatan lembaga dalam kurun waktu satu tahun kedepan. Oleh karena itu dalam anggaran sekolah terdapat gambaran kebutuhan kegiatan yang akan dilaksanakan. Di SMAN 1 Papar Kediri anggaran difungsikan sebagai penaksir kebutuhan biaya yang diperlukan dan rincian kegiatan yang akan

11 Sugiono, Metode Penelitian Pendidikan, 337.

12 Bendahara, Wawancara, SMAN 1 Papar Kediri, 18 Agustus 2018

13 Mulyasa, Menjadi Kepala Sekolah Profesioanal, Bandung: Remaja Rosdakarya,2005, cet ke-5, 149. dilaksanakan, sebagai penaksir berisi perkiraan pendapatan dari berbagai jenis penerimaan dan pengeluaran untuk berbagai kebutuhan sekolah. Selain itu anggaran berfungsi sebagai alat otoritas dalam mengeluarkan dana sesuai dengan perencanaan. Adapun sebagai alat efisiensi, anggaran untuk mengetahui ada tidaknya pemborosan dan juga sebagai pengendali anggaran.berikut petikan wawancara dengan kepala sekolah

Penyusunan anggaran merupakan proses negosiasi antara saya selaku KPA dan guru guru dalam menentukkan besarnya alokasi biaya dan sebagai alat untuk menentukkan skala prioritas. ${ }^{12}$

Hal tersebut divalidasi oleh bendahara Penyusunan anggaran merupakan proses negosiasi antara KPA dengan bendahara dan para wakil kepala dalam menentukkan besarnya alokasi biaya yang akan digunakan untuk segala macam kegiatan yang akan dilakukan di sekolah setahun ke depan. ${ }^{13}$

Dalam penyusunan anggaran, KPA dibantu para wakil kepala melakukan musyawarah besarnya alokasi biaya yang dibutuhkan dalam melaksanakan program yang akan disusun dalam RKAS. Dalam keuangan sekolah anggaran terdiri dari penerimaan dan pengeluaran.

Sumber penerimaan merupakan dana yang diterima oleh lembaga pendidikan dari berbagai sumber yaitu pemerintah pusat, pemerintah daerah dan komite. Sedangkan pengeluaran biasanya dijabarkan dalam pengeluaran langsung, pengeluaran tidak langsung dan pengeluaran lainnya. Di SMAN 1 Papar Kedirianggaran terdiri dari rencana penerimaan dan pengeluaran 14

a) Penerimaan

SMAN 1 Papar Kediri memperoleh dana dari BOS dari pemerintah pusat dan iuran rutin dari orang tua . Dana yang diterima tersebut digunakan untuk

14 Dokumentasi Pemasukan dan Rencana Pengeluaran SMAN 1 Papar Kediri 18 Agustus 2018 
membiayai segala keperluan dan kebutuahan sekolah untuk peningkatan mutu pendidikan. Adapun ilustrasi dana yang diterima adalah sebagai berikut :

b) Pengeluaran

Pengeluaran di SMAN 1 Papar Kediriberupa pengeluaran untuk pembangunan yang berupa penambahan buku perpustakaan, dana untuk anggaran rutin berupa pengeluaran untuk gaji guru dan karyawan, perlengkapan belajar mengajar, listrik, telepon, air, untuk kegiatan ekstrakulikuler dan kegiatan peringatan hari besar nasional atau Islam. Langkah penyusunan anggaran SMAN 1 Papar Kediri dan pendekatan partisipasif dalam penyusunan anggaran adalah sebagai berikut:

Dalam penyusunan anggaran terdapat tiga langkah yang kami lakukan yaitu perencanaan pendidikan, perencanaan pengeluaran untuk berbagai Dokumentasi Pemasukan dan REncana Pengeluaran SMAN 1 Papar Kediri program dan perencanaan pendapatan. Mengenai pendapatan untuk setiap tahunnya SMAN 1 Papar Kedirimengandalkan pendapatan dari pemerintah, guna membiayai kegiatan dan kebutuhan yang mendukung kegiatan sekolah.

Kepala sekolah menggunakan pendekatan partisipatif dalam penyusunan anggaran dengan cara mengidentifikasi kebutuhan untuk melaksanakan program sekolah dan menetapkan skala prioritas.

SMAN 1 Papar Kediri melakukan proses perencanaan yang dilakukan pada tahun ajaran baru dan melibatkan wali murid dan komite sekolah. Sebelum RAKAS dibuat, dari pihak sekolah memberikan surat pemberitahuan kepada wali murid agar hadir dalam proses pembuatan RAKAS. Perencanaan sebagai suatu proses Pencapaian tujuan seefektik dan seefisien mungkin. Dibawah pimpinan kepala sekolah melakukan proses perencanaan dengan memperhatikan berbagai hal melalui data dan informasi yang dikumpulkan dari berbagai pihak. Pihak yang paling berpengaruh adalah wali murid, masyarakat agar visi yang diemban sekolah dapat terwujud. Data tersebut akan dikaji dan pada akhirnya akan disusun sebagai bahan masukan dalam penyusunan RAKAS. Dalam proses penyusunan RAKAS SMAN 1 Papar Kediri melakukan empat kegiatan yaitu:

a) Merencanakan anggaran SMAN 1 Papar Kediri dalam merencanakan anggara pendidikan yang ingin dicapai dibuat berdasarkan visi dan misi sekolah. Sehingga sekolah memperhitungkan dengan matang agar penggunaan dana sesuai dengan kebutuhan .

b) Mempersiapkan anggaran. Dalam mempersiapkan anggaran yang akan dilakukan dalam setahun kedepan. SMAN 1 Papar Kediri berpedoman pada tujuan yang ingin dicapai dengan memperhatikan perkiraan besarnya sumber dana yang diperoleh serta pengalokasian untuk program yang dijalankan.

c) Mengelola pelaksanaan anggaran yaitu mempersiapkan pembukuan, melakukan pembelanjaan, membuat bukti transaksi, membuat perhitungan anggaran dalam berbagai program, serta membuat laporan pertanggungjawaban keuangan. agar nantinya laporan ini dapat disampaikan ke masyarakat. Identifikasi dilaksanakan dengan cara mengumpulkan data dan informasi dari berbagai pihak yang kemudian diolah bendahara dan dipertanggungjawabkan kepada kepala sekolah, komite dan wali murid. Hal ini penting guna kelancaran dan kesuksesan dalam pelaksanaan suatu rencana.

d) Menilai pelaksanaan anggaran. Proses menilai memerlukan masukan dari wali murid dan komite sekolah. Agar penilaian anggaran dalam setiap kegiatan yang memerlukan biaya lebih efektif dan efisien.

Kegiatan di atas dilakukan oleh sekolah untuk menyusun perencanaan yang diharapkan mampu memenuhi kebutuhan sekarang maupun yang akan datang dan dalam proses penyusunan RAKAS, kepala sekolah dibantu wakilnya dan para guru untuk melakukan perundingan dengan wali murid. Perundingan tersebut digunakan untuk menentukkan besar kecilnya alokasi biaya yang dibutuhkan dalam melaksanakan program program yang akan 
disusun yang pada akhirnya akan menjadi RAKAS. Dalam proses perencanaan, perkiraan pendapatan dan pengeluaran kemudian dituangkan dalam RAKAS. Setelah rencana disusun dengan baik maka pada proses selanjutnya adalah mengembangkan rencana tersebut. Dalam proses pengembangan RAKAS di SMAN 1 Papar Kediri meliputi beberapa tahap sebagai berikut :

a) Pada tingkat kelompok kerja yang terdiri dari para pembantu kepala sekolah melakukan identifikasi

terhadap kebutuhan-kebutuhan biaya yang

harus dikeluarkan untuk keperluan penggaran untuk program sekolah ke depan.

b) Pada tingkat komite sekolah. Setelah semua kebutuhan teridentifikasi kelompok kerja bersama komite sekolah mengadakan rapat membahas RAKAS yang sudah dibentuk.

c) Sosialisasi dan legalitas. Pada tahap ini pihak sekolah mengadakan rapat dengan wali murid untuk merundingkan besarnya biaya untuk membiayai semua program yang telah direncanakan dalam RAKAS sehingga wali murid juga merasa memiliki dan bertanggungjawab akan program yang telah direncanakan sekolah. Setelah semua pihak mengetahui akan semua program sekolah maka tahap terakhir adalah pengesahan.

\section{Pelaksanaan Keuangan Sekolah}

Setelah perencanaan keuangan sekolah selesai dan disetujui oleh semua pihak yang terlibat, maka langkah selanjutnya dalam manajemen adalah pelaksanaan terhadap perencanaan yang telah dibuat. Dalam pelaksanaan keuangan sekolah melakukan dua jenis kegiatan yaitu penerimaan terhadap dana pendidikan dan pengeluaran untuk berbagai kebutuhan. Dalam pelaksanaan penerimaan dan pengeluaran diadakan pemisahan antara keduanya yaitu penerimaan dilakukan oleh

15 Buku Panduan DIPA Kemenag

16 Dokumentasi RKAM SMAN 1 Papar Kediritahun 2014/2015 bendahara II dan pengeluaran oleh bendahara I. ${ }^{15}$

a) Penerimaan dana pendidikan

Penerimaan dana pendidikan di

SMAN 1 Papar Kediri ditentukan oleh besarnya dana yang diterima sekolah dari sumber dana.

Dalam melaksanakan penerimaan ini, SMAN 1 Papar Kediri membuat pembukuan yang berdasarkan prosedur pengelolaan yang telah ditetapkan kepala sekolah. Dalam buku penerimaan dana sekolah dibuat oleh bendahara II yang berisi semua dana yang masuk dicatat dalam dalam buku harian. Buku ini berisi nama penyetor, kelas, guna membayar dan jumlah uang yang disetorkan. Uang yang masuk dalam buku harian. Setiap uang yang masuk kemudia direkap. ${ }^{16}$

b) Pengeluaran dana pendidikan

Dalam pelaksanaan keuangan,

SMAN 1 Papar Kedirimempercayakan pengelolaan pengeluaran dana pendidikan kepada bendahara I. Dalam prakteknya pengeluaran dana digunakan untuk pengeluaran dana langsung yang terdiri dari gaji, tunjangan guru dan tenaga kependidikan, kegiatan pembelajaran, ATK, perjalanan dinas, penggandaan soal, daya dan jasa serta biaya tak terduga lainnya. Sedangkan biaya tidak langsung meliputi pemeliharaan dan pengembangan sarana prasarana. ${ }^{17}$

Berikut petikan wawancara dengan kepala sekolah : Bendahara II bertugas mencairkan dana untuk berbagai kegiatan di SMAN 1 Papar Kediri ini tentunya harus sesuai dengan prosedur yang telah kami tetapkan. ${ }^{18}$

Hal tersebut juga divalidasi oleh kepala sekolah berikut wawancara peneliti dengan bendahara : Tugas saya adalah mengeluarkan dana demi kelancaran kegiatan belajar mengajar di SMAN 1 Papar Kediritentunya dengan prosedur yang telah kami sepakati. Adapun proses pengeluaran dana di SMAN 1 Papar Kediriadalah sebagai berikut ini: a. Setiap permintaan

\footnotetext{
17 Kepala, Wawancara, SMAN 1 Papar Kediri, 19 Agustus 2018

18 Bendahara, Wawancara, SMAN 1 Papar Kediri, 19 Agustus 2018
} 
pengeluaran dana harus ditulis dalam lembar permintaan atau dibuat proposal kegiatan, b. Yang mengajukan permintaan pengeluaran dana mengajukan lembar permintaan tersebut ke kepala sekolah untuk mendapatkan persetujuan pengeluaran dana. Kepala sekolah akan menelitinya dan akan menandatangani apabila disetujui atau menolaknya. Persetujuan kepala sekolah ini berarti adanya perintah pengeluaran dana kepada bendahara sekolah, c. Setelah kepala sekolah menyetujuinya maka penanggungjawab kegiatan mengajukannya kepada bendahara. Bendahara akan mengecek dan menelitinya, d. Setelah diteliti dan sudah ditandatangani kepala sekolah, maka bendahara akan mengeluarkan dana untuk keperluan belanja sekolah. ${ }^{19}$

Tahapan di atas guna pengendalian dan pengawasan terhadap dana yang dikeluarkan sehingga pada akhirnya dapat dipertanggungjawabkan dengan baik. Dalam manajemen pembiayaan sekolah, pelaksanaan keuangan sekolah juga dilakukan pembukuan guna untuk mencatat semua permintaan pengeluaran dana secara kronologis pada setiap transaksi. Berikut wawancara dengan bendahara I.

Selain mencatat setiap pengeluaran saya juga membuat laporan keuangan baik itu bulanan ataupun pertangggungjawaban pada akhir tahun. ${ }^{20}$

Secara umum laporan keuangan bertujuan untuk memberikan informasi tentang kondisi keuangan, kinerja dan arus kas untuk membuat keputusan ekonomi dan laporan keuangan, juga menunjukkan satu pertanggungjawaban pihak manajemen keuangan terhadap internal maupun eksternal sekolah. Laporan bulanan digunakan sebagai pembanding pendapatan dan pengeluaran. Laporan yang dibuat oleh bendahara kemudian diserahkan kepada KPA dengan tujuan agar KPA mengetahui kondisi keuangan dan

19 Kepala , Wawancara, SMAN 1 Papar Kediri, 19 Agustus 2018

${ }^{20}$ Kepala, Wawancara, SMAN 1 Papar Kediri, 19 Agustus 2018 dapat membandingkan pengeluaran untuk setiap tahunnya. Selain itu juga sebagai bentuk laporan pertanggungjawaban untuk mendapat pengesahan.

\section{c) Pemeriksaan anggaran}

Pemeriksaan anggaran dilakukan baik internal maupun eksternal. Internal dilakukan oleh kepala sekolah dan eksternal dilakukan oleh komite sekolah. Pemeriksaan ini digunakan untuk melihat kebijakan pengeluaran terhadap kebutuhan untuk melaksanakan program sekolah dan kebutuhan penunjang pelaksanaan kegiatan belajar mengajar di sekolah yang bertujuan untuk peningkatan mutu.

d) Pemeriksaan Kas

Pemeriksaan kas ini bertujuan untuk menguji kebenaran data dengan kenyataan uang yang ada, apabila ada selisih uang maka bendahara harus dapat menjelaskan keadaan keuangan yang sebenarnya tanpa ditutup tutupi berikut petikan wawancara dengan kepala sekolah;

Pemeriksaan ini kami lakukan dengan mencocokkan catatan dana bendahara II yaitu dana yang diterima sekolah dengan catatan yang dibuat oleh bendahara I yaitu pengeluaran dana. Apakah sudah singkron atau belum. ${ }^{21}$

Pemeriksaan ini biasanya dilakukan dalam waktu dan tempat yang terpisah atau mereka melakukan pemeriksaan sendiri sendiri. hasil pemeriksaan kas ini akan dapat diketahui adanya kebocoran keuangan atau tidak.

e) Pemeriksaan barang

Pemeriksaan barang dilakukan terhadap kekayaan sekolah. Pemeriksaan ini bertujuan menilai layak tidaknya barang yang dibeli, yang pada akhirnya akan mempengaruhi penentuan pembelian barang berikutnya.

Selain pemeriksaan terhadap ketiga hal di atas kepala sekolah dan komite juga melakukan pemeriksaan dan penilaian terhadap laporan pertanggungjawaban keuangan yang dibuat bendahara baik bulanan atau tahunan. Pemeriksaan ini

${ }^{21}$ Komite, Wawancara, SMAN 1 Papar Kediri, 19 Agustus 2018 
dilakukan guna mengetahui pemasukan dan pengeluaran pada akhir tahun sebagai kumpulan dari beberapa bulan selama satu tahun anggaran.

\section{Strategi Peningkatkan Mutu Lembaga Pendidikan Islam}

Strategi peningkatan mutu pendidikan khususnya pendidikan di SMAN 1 Papar Kediri merupakan faktor terpenting dalam meningkatkan kualitas sumber daya manusia. Dengan kata lain sekolah di tuntut untuk dapat menghasilkan anak didik yang maju dan tanggap terhadap perkembangan zaman. Untuk itu sekolah perlu mengelola komponen pendidikan secara optimal agar dalam proses pembelajaran berorientasi pada peningkatan mutu pendidikan.

Mutu pendidikan menurut SNP adalah pendidikan yang menghasilkan lulusan yang sesuai dengan harapan masyarakat baik dalam kualitas pribadi moral, pengetahuan, maupun kompetensi kerja menjadi syarat mutlak dalam kehidupan masyarakat global yang terus berkembang saat ini. Mutu Pendidikan di di SMAN 1 Papar Kediri diukur dengan criteria yang berdasarkan SNP yang meliputi Standar isi, standar proses, standar kompetensi kelulusan, standar pendidik dan tenaga kependidikan, standar sarana prasarana, standar pengelolaan, standar pembiayaan dan standar penilaian.

Peneliti melakukan wawancara untuk mengetahui tentang strategi peningkatan mutu pendidikan di SMAN 1 Papar Kediri dengan kepala sekolah. Berikut ini petikan wawancaranya.

Sekolah kami juga melakukan strategi peningkatan mutu pendidikan. Strategi tersebut kami lakukan agar peningkatan mutu di sekolah dapat tercapai dengan baik sehingga memudahkan dalam pencapaian tujuan pendidikan. Selain itu, dilakukannya strategi peningkatan mutu juga untuk mengetahui sejauh mana hasil mutu pendidikan yang dicapai. ${ }^{22}$

\footnotetext{
22 Kepala , Wawancara, SMAN 1 Papar Kediri, 18 Agustus 2018

${ }^{23}$ Wakil kepala Kurikulum, Wawancara, SMAN 1 Papar Kediri, 18 Agustus 2018
}

Pernyataan di atas dibenarkan oleh wakil kepala bagian Kurikulum yang menyatakan sebagai berikut.Strategi peningkatan mutu pendidikan kami lakukan untuk mempermudah dalam pencapaian mutu pendidikan di sekolah kami. Dengan melakukan strategi ini kami akan lebih, mudah mengetahui dan membenahi kekurangan kekurangan yang ada. ${ }^{23}$

Berdasarkan hasil wawancara di atas dapat diketahui bahwa strategi peningkatan mutu pendidikan di SMAN 1 Papar Kediri adalah untuk memudahkan sekolah menganalisis kekurangan dalam proses peningkatan mutu. Dalam mendiagnosis kebutuhan, SMAN 1 Papar Kediri sangat memperhatikan kebutuhan peserta didik, disamping memperhatikan kebutuhan peserta didik diagnosis juga tidak boleh keluar dari visi misi sekolah sebagai model lembaga pendidikan umum dan relevansinya terhadap kebutuhan masyarakat serta kebijakan pemerintah tentang KTSP. Dalam mengatur strategi peningkatan mutu pendidikan di sekolah. kepala sekolah dibantu oleh wakil kepala kurikulum berikut wawancara peneliti dengan kepala sekolah.

Dalam menentukan perencanaan peningkatan mutu pendidikan pada sekolah, kami mengundang komite sekolah, Mapenda, wali murid dan semua unsur yang terkait agar memberikan saran untuk peningkatan mutu pendidikan. ${ }^{24}$

SMAN 1 Papar Kediri dalam mengatur strategi peningkatan mutu pendidikan selalu melibatkan berbagai pihak baik itu UPTD Pendidikan, Mapenda, komite, guru dan karyawan serta wali murid. Peneliti melakukan wawancara dengan wakil kepala kurikulum untuk mengetahui pendekatan yang digunakan dalam strategi peningkatan mutu pendidikan di SMAN 1 Papar Kediri. Berikut ini petikan wawancaranya

Pendekatan yang kami lakukan untuk peningkatan mutu pendidikan yaitu

${ }^{24}$ Kepala , Wawancara, SMAN 1 Papar Kediri, 18 Agustus 2018 
pertama, kami selalu memperbaiki mutu secara terus menerus, menentukan standar yang akan dicapai, menanamkan tentang pentingnya meningkatkan mutu pendidikan, kami selalu menjalin hubungan baik dengan para wali siswa karena mereka adalah patner kami hal ini kami lakukan untuk memenuhi kebutuhan konsumen. ${ }^{25}$

Peryataan di atas divalidasi oleh kepala SMAN 1 Papar Kediri tentang pendekatan strategi peningkatan mutu pendidikan oleh kepala sekolah.

Kami senantiasa melakukan berbagai hal diantaranya : a) perbaikan dan peningkatan mutu secara terus menerus, yang disesuaikan dengan kebutuhan para pelanggan kami, b) Menentukan standar mutu materi kurikulum, evaluasi, standar mutu proses pembelajaran, yang nantinya diharapkan dapat maksimal dalam proses produksi dan dapat melahirkan produk yang menguasai standar mutu pendidikan, c) merubah cara pandang agar lebih menghargai mutu, saya berusaha membangun kesadaran guru, siswa, wali siswa, staf dan semua unsur yang terkait akan pentingnya mempertahankan dan meningkatkan mutu pembelajaran, baik mutu hasil maupun mutu proses, d) perubahan organisasi, jika visi misi serta tujuan lembaga berubah atau mengalami perkembangan maka otomatis terjadi perubahan struktur organisasi. Hal ini menyangkut perubahan kewenangan tugas dan tanggungjawab, e) mempertahankan hubungan dengan pelanggan. ${ }^{26}$

Berdasarkan hasil wawancara di atas dapat kami simpulkan SMAN 1 Papar Kediri selalu berusaha menggandeng semua steakholder untuk membicarakan strategi peningkatan mutu pendidikan dengan melakukan berbagai pendekatan agar dapat tercapai mutu pendidikan yang telah ditentukan. Adapun langkah-langkah yang dilakukan sekolah untuk mencapai tujuan dalam meningkatkan mutu pendidikan sekolah :

25 Wakil kepala Kurikulum, Wawancara, SMAN 1 Papar Kediri, 18 Agustus 2018

${ }^{26}$ Kepala , Wawancara, SMAN 1 Papar Kediri, 18 Agustus 2018
Sebenarnya semua kegiatan yang ada di sekolah yang bertanggungjawab adalah saya, tetapi dalam pelaksanaannya saya dibantu oleh para bapak dan ibu guru. Seperti peningkatan mutu pendidikan, maka yang membantu adalah tim peningkatan mutu yang dikoordinir oleh wakil kepala kurikulum. Tugas dari tim peningkatan mutu ini ialah mengawasi proses pengembangan di SMAN 1 Papar Kediri, mengusulkan pemecahan masalah di SMAN 1 Papar Kediri, dan mengusulkan perubahan kurikulum sesuai dengan perkembangan zaman misalnya memberi tambahan kursus komputer, mengembangkan sumber daya manusia, dan mengembangkan profesionalisme guru. ${ }^{27}$

Agar mutu dapat tercapai sesuai dengan target yang telah ditentukan maka kerjasama tim sangat efektif dilakukan, semua pihak ikut terlibat dalam peningkatan mutu SMAN 1 Papar Kediri, baik buruknya mutu pendidikan menjadi tanggungjawab bersama. Mutu pendidikan di SMAN 1 Papar Kediri dilaksanakan sesuai dengan standar SNP berikut wawancara dengan kepala sekolah:

Kriteria yang kami patok dalam meningkatkan mutu pendidikan kami sesuaikan dengan standar SNP. Hal ini juga di validitas oleh wakil kurikulum. Untuk kriteria mutu kami sesuaikan dengan standar SNP yang meliputi standar isi, standar proses, stndar kompetensi lulusan, standar pendidik dan tenaga kependidikan, standar sarana prasarana, standar pengelolaan, standar pembiayaan dan standar penilaiaan SMAN 1 Papar Kediri telah menetapkan 8 standar untuk mengukur tingkat pencapaian mutu pendidikannya. Hal ini sesuai dengan standar yang ditetapkan SNP. Sehingga sekolah perlu membuat terobosan untuk peningkatan mutu Berikut ini pernyataan kepala sekolah. Untuk peningkatan mutu, sekolah membuat langkah langkah antara lain: melakukan evaluasi diri yang

${ }^{27}$ Kepala , Wawancara, SMAN 1 Papar Kediri, 18 Agustus 2018 
dilakukan setiap kali rapat, merumuskan visi, misi dan tujuan sekolah. ${ }^{28}$

Hal senada juga diungkapkan oleh wakil kepala kurikulum. Adapun langkah langkah yang ditempuh sekolah dalam meningkatkan mutu pendidikan antara lain: melakukan Evaluasi diri, merumuskan visi dan misi serta tujuan sekolah yang sesuai dengan perkembangan dan tuntutan jaman. $^{29}$

Evaluasi diri bertujuan untuk perbaikan sekolah kedepannya dalam perbaikan mutu sekolah. Evaluasi ini dilaksanakan setiap diadakan rapat untuk mengetahui kendala apa yang terjadi dalam komponen ketenagaan, sarana dan prasarana, pembiayaan serta programprogam sekolah lainnya untuk mendapatkan solusi dari kendala tersebut. Kedua Merumuskan visi, misi dan tujuan Sekolah hal ini di harapkan sesuai dengan visi dan misi pendidikan di SMAN 1 Papar Kediri yaitu mempersiapkan peserta didik menjadi manusia yang shaleh akrom yaitu manusia yang beriman dan bertaqwa terhadap tuhan yang maha esa, berbudi luhur, memiliki pengetahuan dan ketrampilan, kesehatan jasmani dan rohani, kepribadian yang mantap dan mandiri serta rasa tanggung jawab kemasyarakatan dan kebangsaan.

Perencanaan dibuat untuk memudahkan sekolah dalam membuat terobosan guna peningkatan mutu. Perencanaan ini dibuat di awal tahun dan dibahas dalam rapat perencanaan yang dipimpin oleh kepala sekolah dan dihadiri semua staf sekolah. Dalam rapat tersebut membahas tentang perencanaan anggaran RAKAS guna peningkatan mutu dalam satu tahun ke depan dibahas dan dianggarkan serta dibuat skala prioritas. Adapun program yang dicanangkan SMAN 1 Papar Kediri berikut wawancara dengan kepala sekolah:

Program yang kami buat untuk peningkatan mutu antara lain peningkatan kualitas guru, peningkatan prestasi siswa

${ }^{28}$ Kepala, Wawancara, SMAN 1 Papar Kediri, 18 Agustus 2018

${ }^{29}$ Wakil kepala Kurikulum, Wawancara, SMAN 1 Papar Kediri, 18 Agustus 2018 baik akademik ataupun non akademik serta peningkatan sarana prasarana.

Adapun Program yang dicanangkan SMAN 1 Papar Kediri meliputi:a. Peningkatan kualitas guru melalui pelatihan, seminar, workshop, b. Peningkatan prestasi akademik melalui bimbingan belajar dan prestasi non akademik melalui kegiatan ekstrakulikuler, c. Peningkatan sarana prasana yang menunjang kegiatan belajar mengajar. Dalam pelaksanaan peningkatan mutu kepala sekolah dibantu berbagai pihak Berikut pernyataan kepala sekolah

Saya di bantu tim peningkatan mutu yang selalu memonitoring semua kegiatan yang ada di SMAN 1 Papar Kediri ini, kami melakukan rapat setiap sebulan sekali. Hal ini kami lakukan untuk mengetahui bagaimana pelaksanaan semua kegiatan yang berjalan di SMAN 1 Papar Kediri. ${ }^{30}$

Hal ini senada dengan yang dikatakan oleh wakil kepala kurikulum. Di SMAN 1 Papar Kediri ini selalu melakukan rapat rutin sebulan sekali untuk membicarakan tentang hal hal yang berhubungan dengan peningkatan mutu pendidikan, apakah sudah berjalan dengan baik atau belum, dan mana yang perlu kita benahi. ${ }^{31}$

Untuk evaluasi belajar diukur melalui kehadiran siswa dalam mengikuti pelajaran, ekstrakulikuler di sekolah, kehadiraan siswa, penilaian akhlak mulia siswa dan rapor. Laporan semua bidang dilaporkan setiap tahunnya kepada kepala sekolah. Berikut wawancara peneliti dengan wakil kepala kurikulum

Laporan semua kegiatan di sekolah di lakukan di akhir tahun pelajaran, dalam hal ini masyarakat akan merasa terpuaskan jika sekolah dapat melaksanakan proses pembelajaran yang bermutu. Mutu dapat dilihat jika di sekolah tersebut peserta didiknya telah mengalami perubahan baik sikap, perilaku, maupun bertambahnya

\footnotetext{
${ }^{30}$ Kepala , Wawancara, SMAN 1 Papar Kediri, 18 Agustus 2018

${ }^{31}$ Kepala , Wawancara, SMAN 1 Papar Kediri, 18 Agustus 2018
} 
pengetahuan dan ketrampilan peserta didik yang bersekolah di sekolah ini. ${ }^{32}$

Adapun pernyataan kepala sekolah adalah sebagai berikut : Pelaporan semua kegiatan di sekolah dilakukan di akhir tahun pelajaran, dengan harapan masyarakat akan merasa terpuaskan terhadap proses pembelajaran yang bermutu. Mutu dapat dilihat jika di sekolah tersebut peserta didiknya telah mengalami perubahan baik sikap, perilaku, maupun bertambahnya pengetahuan dan ketrampilan peserta. Namun semua itu tidak dapat terlepas dari pembiayaan sekolah dalam mengalokasikan biaya pendidikan terhadap kebutuhan peningkatan mutu pendidikan. ${ }^{33}$

Semua kegiatan di SMAN 1 Papar Kediri akan dilaporkan dan dipertanggungjawabkan pada setiap akhir pembelajaran dan semua pihak atas amanah yang diberikan sekolah. Dengan harapan agar mutu sekolah dapat terpantau dan diukur tingkat keberhasilannya. Sedangkan faktor pendukung peningkatan mutu lembaga pendidikan meliputi tenaga pendidik yang berlatarbelakang SI, Sekolah memiliki program yang jelas, lingkungan sekolah yang kondusif. Sedangkan faktor penghambat meliputi: Masih rendah tingkat kedisplinan guru dan ketersedian dana sekolah yang masih terbatas.

\section{Kesimpulan}

Berdasarkan hasil penelitian tentang strategi peningkatan mutu melalui manajemen pembiayaan (studi kasus pada SMAN 1 Papar Kediri) dapat disimpulkan sebagai berikut:

1. Perencanaan manajemen pembiayaan pendidikan di SMAN 1 Papar Kediri telah melibatkan partisipasi aktif dari semua pihak hal ini dilakukan untuk mengurangi beban biaya dalam penyelenggaraan pendidikan. Penggunaan anggaran pembiayaan pendidikan yang telah sesuai dengan program pembiayaan yang telah ditetapkan merupakan faktor kunci terlaksana proses pendidikan di sekolah. SMAN 1 Papar Kediri cenderung lebih memprioritas kebutuhan yang

32 Wakil kepala kurikulum, Wawancara, SMAN 1 Papar Kediri, 18 Agustus 2018 menunjang peningkatan mutu pendidikan agar pembiayaan dapat berjalan efektif dan efisien. Dalam pembiayaan SMAN 1 Papar Kediri cenderung menunggu kucuran dana dari pemerintah saja. Pelaksanaan keuangan sekolah di di SMAN 1 Papar Kediri sudah berjalan baik dan perlu dipertahankan dan ditingkatan kinerjanya. Pembiayaan di SMAN 1 Papar Kediri sudah dikelola secara professional.

2. Penggunaan dan pertanggungjawaban manajemen pembiayaan pendidikan di SMAN 1 Papar Kediri untuk meningkatkan mutu pendidikan adalah dengan membentuk tim peningkatan mutu yang bertugas merencanakan, melaksanakan, mengevaluasi mutu pendidikan di SMAN 1 Papar Kediri. Penyelenggaraan pendidikan yang berdasarkan SNP dalam perencanaan, pelaksanaan dan pengawasan pendidikan bertujuan menjamin mutu pendidikan nasional. SMAN 1 Papar Kediri telah memenuhi SNP. Pencapaian ini di dukung berbagai faktor diantaranya yaitu peserta didik, kurikulum dan sarana prasarana sedangkan faktor penghambatnya adalah sistem penilaian pendidikan yang hanya fokus pada hasil pembelajaran dan kurang memperhatikan penilaian proses pembelajaran.

3. Implementasi peningkatan mutu pendidikan dan upaya mengatasi hambatan berdasarkan SNP meliputi kerangka dasar dan struktur kurikulum, beban mengajar dan kalender pendidikan telah dijabarkan dan diimplementasikan dalam proses pembelajaran sesuai dengan SNP. Pengelolaan system Manajemen yang baik akan mendukung proses pembelajaran yang baik dan menghasilkan peningkatan mutu pendidikan.Berdasarkan hasil analisis mutu pendidikan pendidikan berkorelasi positif dan signifikan dengan manajemen pembiayaan dimana dengan manajemen pembiayaan sekolah mampu merencanakan hal hal yang menunjang peningkatan mutu misalnya dengan pembiayaan yang handal akan menunjang pengadaan sarana prasarana yang

${ }^{33}$ Kepala , Wawancara, SMAN 1 Papar Kediri, 18 Agustus 2018 
menunjang pembelajaran, pengembangan diri guru serta prestasi akademik dan non akademik siswa.

Dengan demikian manajemen pembiayaan memegang peranan yang sangat vital dalam meningkatkan mutu pendidikan di SMAN 1 Papar Kediri.

\section{Daftar Pustaka}

Mulyasa, 2007. Manajemen Berbasis Sekolah. Bandung. Remaja Rosda Karya.

Dimock, ME. Dimock, GO. 1992. Administrasi Negara. Jakarta. Rineka Cipta.

Sulthon, M. Khusnuridlo, M,2006. Manajemen Sekolah Dalam Perspektif Global, 2006, Yogyakarta, laksBang PRESSindo.

Abdul, Hadis \& Nurhayati. 2010. Manajemen Mutu Pendidikan. Bandung: AlfaBeta.

Andrian, Arkanudin, Gusti Suryansyah. 2013 Implementasi Pengembangan Manajemen Berbasis Sekolah di SMKN 1 Kab. Sintang", Jurnal Tesis PMIS-UNTAN-PSIAN

Achmad, Dedy. 2011. Pengelolaan Pembiayaan Sekolah Dasar di Bandung, Jurnal Penelitian Pendidikan Vol.12. No I, April 2011.

Ahmadi, Rulam. 2005. Memahami Metodologi Penelitian Kualitatif, Malang: Universitas Negeri Malang Press.

Armida. 2011. Sistem Anggaran Pendidikan (Studi Tentang Sistem Penganggaran Pendidikan dan Efektivitas Penggunaan Biaya Pendidikan serta Dampaknya Terhadap Peningkatan Mutu Pendidikan Sekolah Aliyah di Kota Jambi)", Jurnal Penelitian Pendidikan Volume 12, Nomor 1, diakses tg1 1 April 2011.

Atmodiwiryo, Soebagio. 2000. Manajemen Pendidikan Indonesia, Jakarta: Ardadizya Jaya.
Arikunto, Suharsimi. 2006. Prosedur Penelitian Suatu Pendekatan Praktik Jakarta: Rineka Cipta.

Ba'haqi, Nazir, Zahra. 2012. Manajemen Pembiayaan pendidikan pada SMKN di Kab. Aceh Besar",Jurnal Administrasi Pendidikan Program Pasca Sarjana Syiah Kuala, Volume 1, Nomor 1.

Bafadal, Ibrahim. 2002. Manajemen Peningkatan Mutu Sekolah Dasar: dari Sentralisasi Menuju Desentralisasi, Jakarta: PT Bumi Aksara, cet 2.

Budi Santoso. 2012. Manajemen Pembiayaan Pendidikan Pada Sekolah Dasar yang Efektif (Studi Multi Kasus Sekolah Dasar Panglima Sudirman, Sekolah Dasar Abdul Rahman, dan Sekolah Dasar Welirang di Kota Batu). Disertasi, Program Studi Manajemen Pendidikan, Program Pascasarjana Universitas Negeri Malang.

Bungin, Burhan. 2010. Analisis Data Penelitian Kualitatif;Pemahaman Filosofis dan Metode Logis ke Arah Penguasaan Model Aplikasi, Jakarta: Rajawali Pers.

Barnadib.Imam. 1986. Sistem Pendidikan Nasional Menurut Konsep Islam dalam "Islam dan Pendidikan Nasional, Jakarta: Lembaga Penelitian IAIN.

Depdiknas dan Kemenag, 2014. Buku Panduan BOS dan BOS buku.

E Mulyasa. Manajemen Berbasis Sekolah, Bandung: Remaja Rosdakrya, 2005.

Fatah, Nanang. 2014. Ekonomi dan Pembiayaan Pendidikan, Bandung: Remaja, Rosdakarya.

Harsono. 2007. Pengelolaan Biaya Pendidikan, STAIN Surakarta.

Harjo.Budi, Sabar. 2012. Evaluasi Trend Kualitas Pendidikan di Indonesia, Jurnal 
Jurnal Dendidikan dan Studi Keislaman

Penelitian dan Evaluasi Pendidikan, Tahun 16, Nomor 2.

Hasbi. 2013. Peningkatan Mutu Pendidikan Sekolah Dalam Sistem Pendidikan Nasional di kota Palopo Tahun 20112012, Jurnal Diskursus Islam, Volume 1 Nomor 3, Desember 2013 penilaian pendidikan STAIN Datuk Sulaiman Palopo.

Hadi,Sutrisno. 2000. Metode Research II, Yogyakarta: Andi Offset. 